\title{
Exhibiting Aboriginal industry: a story behind a 're-discovered' bark drawing from Victoria
}

\author{
Elizabeth Willis
}

\begin{abstract}
An etching on bark, made before September 1854 by an un-named member of the 'Loddon and Murray tribes' in Victoria, was recently 're-discovered' in England in a back storage area of the Royal Botanic Gardens, Kew. ${ }^{1}$ This drawing once formed part of the first systematic display of Aboriginal material held in Victoria and was later displayed in Paris at the Exposition Universelle of 1855. Only three bark drawings executed by Indigenous Australians in south-eastern Australia during the 19th century are now known to survive. Another drawing, from the same time and with a similar provenance, is held in the British Museum, ${ }^{2}$ while the third, drawn perhaps 15 years later by an Aboriginal person from near Lake Tyrrell in the Mallee district of Victoria, is in the collection of Museum Victoria. ${ }^{3}$
\end{abstract}

In this paper, I describe the transfer of the Kew bark drawing from the artist to a European collector, trace its journey from the Loddon to the Economic Botany Collection at Kew Gardens, and comment on the presentation of Australian Indigenous culture at exhibitions in London in 1851 and in Bendigo, Melbourne and Paris in 1854 and 1855. I also make some preliminary comments about the work itself. In tracing the drawing's 'cultural biography', I argue that it, and other Indigenous material displayed in 1854 and 1855, was collected and exhibited to demonstrate the 'industry' or work of Indigenous people. This aim was largely absent from exhibitions of Indigenous material later in the 19th century.

The bark drawing at Kew, executed on a piece of curved bark that is now split in two places, is a representational work that appears to show a group of men dancing in a corroboree. The existence of a figurative, naturalistic Indigenous art in south-east Australia, particularly along the Murray River and its southern tributaries, is well-attested by contemporary European observers. During March and April 1843 Chief Protector Robinson saw bark drawings - 'rude drawings of humans \& drays', figures of men and emus dancing, and a drawing of the spearing of a white man - on the inside of

\footnotetext{
Centre for Economic Botany, Royal Botanic Gardens, Kew, (Kew EBC 55386) (64 x 35cm).

British Museum, No. Oc.1827 (66 x 31cm).

Museum Victoria, Department of Indigenous Cultures, X1520 (86 x 56cm).
} 
bark huts at camps on the Murray and Loddon Rivers. ${ }^{4}$ Gerard Krefft, collecting natural history specimens for the new National Museum of Victoria in 1857, saw Aboriginal drawings - 'a few tracings on sheets of blackened bark, probably done during a rainy day $^{\prime}$ - on the Murray. ${ }^{5}$ Squatter Phillip Chauncy reported:

On the Murray River, where they used to cover their huts with bark, the young men often amused themselves with carving, or drawing with charcoal, on the inside of the bark, various objects and scenes in illustration of any events they desired to record. ${ }^{6}$

Some of these drawings were made with charcoal on a smoothed surface. Squatter EM Curr recalled the activities of the Bangerang tribe on the Murray and Goulburn Rivers: 'occasionally ... the men drew pictures of corroborees or hunting scenes, with charcoal, on the sheets of bark of which their mia-mias were composed' ${ }^{7}$ A more patronising tone was taken by settler GT Lloyd, who described how Victorian Aboriginal men 'sometimes attempt to delineate with a piece of charcoal, horses, carts and other things' 8

Other drawings were etched into a blackened surface. R Brough Smyth described how the drawing from Lake Tyrrell was made:

the bark was smoked on the inside by placing it over a fire of twigs and leaves, until the surface was blackened but not charred ... the artist drew the figures with the nail of his thumb ... or a piece of bone.

The two other surviving bark drawings from Victoria, in the Kew and British Museum collections, are also etched into soot-blackened bark. It is possible that these drawings were originally located on the inside surfaces of bark huts where smoke-blackening occurred naturally. However, I suggest in this paper that the bark pieces may have been deliberately prepared by the artists, who created two works that they knew were to be part of an exhibition.

The Museum Victoria bark drawing was given to Robert Brough Smyth by Theo J Sumner, who received it from William Stanbridge, a pioneer squatter at Lake Tyrrell who had collected it and brought it to Melbourne before $1874 .{ }^{10}$ The other two Victorian bark drawings now in London were sent to Paris in 1855 by John Hunter Kerr, a squatter who took up land on the Loddon River in 1849.

\section{JH Kerr and the Loddon people}

John Hunter Kerr emigrated from Scotland at the age of 18 in 1839, and first took up land near Heidelberg, on the outskirts of Melbourne. The 1840s depression that ruined many of Port Phillip's gentlemen squatters left him in financial difficulties. He moved from his station and settled on a farm on the Yarra flats, later returning to Scotland for two years. On his return to the colony in 1849 he purchased a property on the Loddon, which he renamed Fernyhurst. This was a station of 89,000 acres which he and his part-

Clark 1988: 67,71,73, cited in Cooper 1994: 105.

Krefft 1862-5: 374, cited in Groger-Wurm 1973: 1.

Chauncy, in Smyth 1878 vol 2: 258, cited in Sayers 1994: 142.

Curr 1883 [1965]: 132.

Lloyd 1862: 465, cited in Groger-Wurm 1973: 1.

Smyth 1878 vol I: 286-287, cited in Massola 1958: 125.

Sculthorpe 1990: 54. 


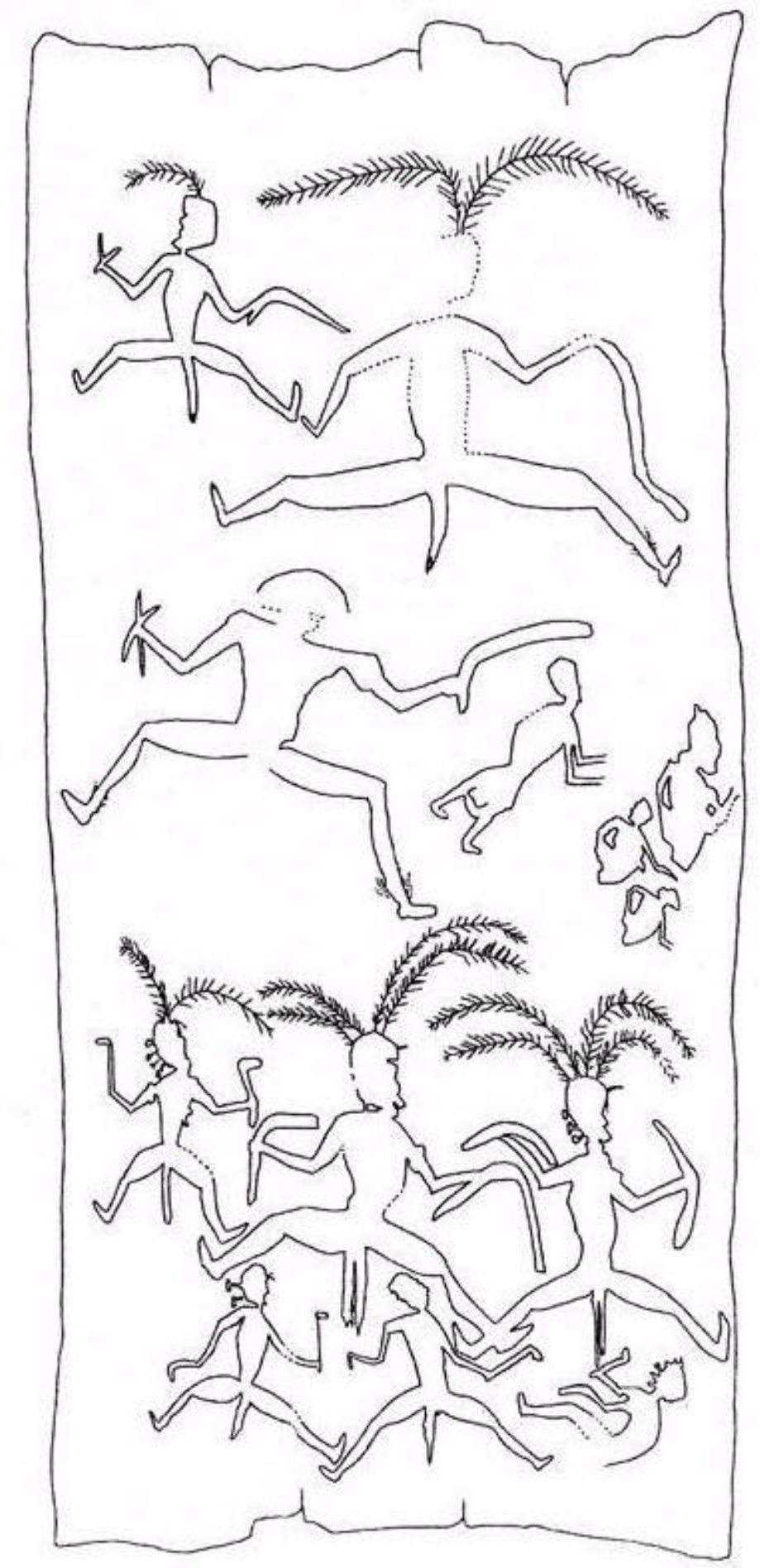

Figure 1: Schematic representation of the bark etching in the collection of the Royal Botanic Gardens, Kew. Drawing by Lindsay Kerr, Royal Botanic Gardens, Kew 


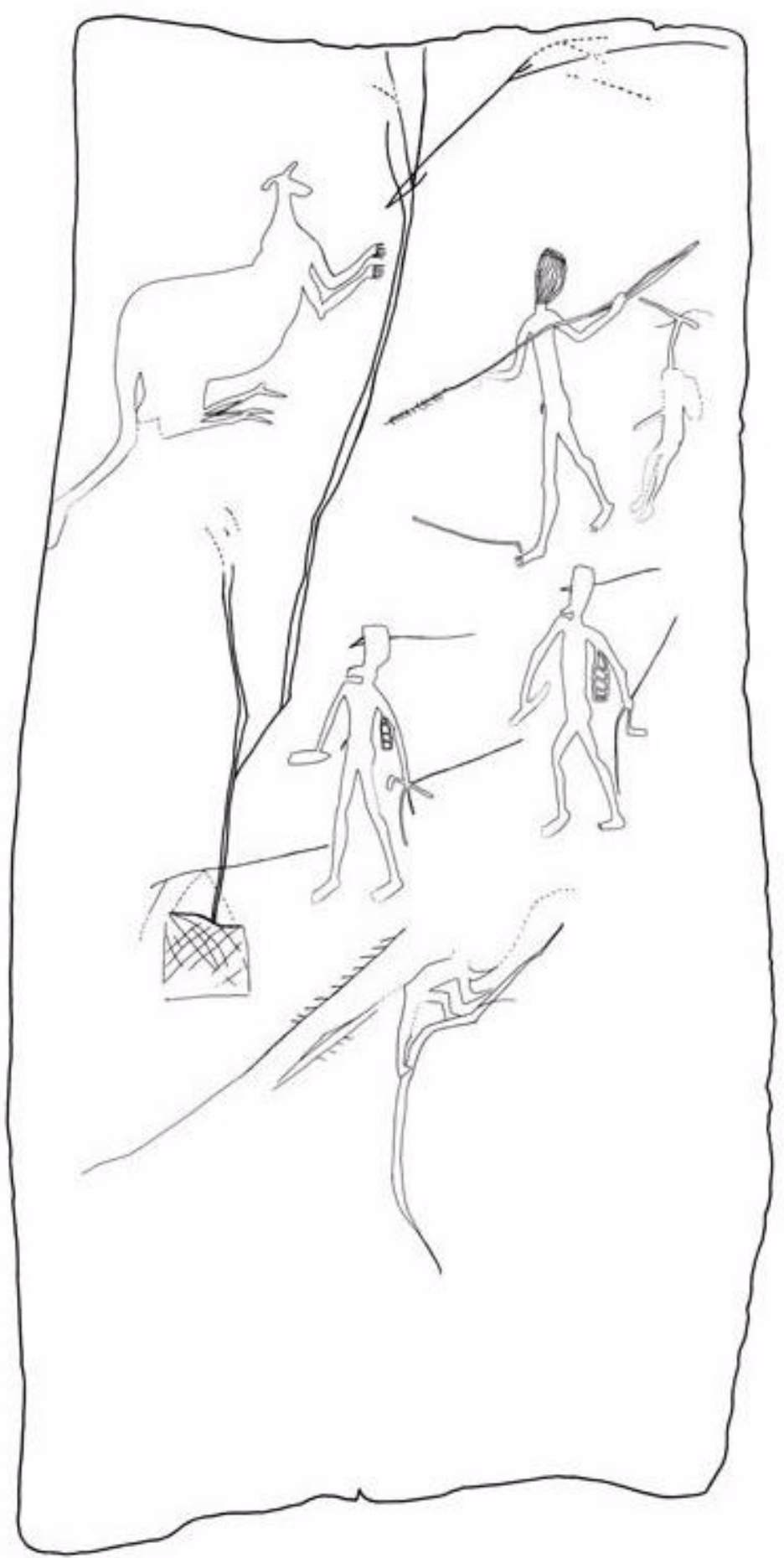

Figure 2: Schematic representation of the bark etching in the collection of the British Museum. Drawing by Lindsay Kerr, Royal Botanic Gardens, Kew 
ner stocked with sheep and cattle. He sold meat to the diggers on the Korong goldfields and was obviously a person of some importance in the local community as he was appointed a magistrate in 1854. However, he was an unsuccessful squatter. 'Bad seasons and adverse circumstances', including the 'dissipation' of his partner, were reasons given for Kerr's failure after his death. He was forced to sell Fernyhurst in 1855 but stayed on the property, possibly as manager, until $1861 .^{11}$

Kerr wrote anonymously a volume of reminiscences that was published in Edinburgh in $1872 .{ }^{12}$ The impression given in the autobiography is of a man with considerable enthusiasm for living and a great curiosity about his new environment. He was interested in his 'Aboriginal neighbours', both in Heidelberg and at the Loddon, and claimed to have been 'always on very friendly terms' with them. He described accompanying them on hunting expeditions for kangaroo, possum, and wild turkey, and wrote of the patient perseverance and trustworthiness of the Indigenous people he knew. While he shared the contemporary belief that 'the doom of their race was fixed, and that, in obedience to the mysterious decree of Providence, they were passing away to give place to a superior race', he was interested to record the transition from what he called 'the savage pur et simple' to a people 'undergoing a great change of habits and character since their intercourse with white men' ${ }^{13}$ A few years before Kerr arrived at Fernyhurst, the Murray and Loddon tribes had already been recorded as having declined in population by $10-12$ percent. ${ }^{14}$

John Kerr's station house was close to an Aboriginal camp and he writes about visits to and from the camp, for example describing his attendance at the burial of a chief and reporting conversations with his 'quiet inoffensive neighbours' about their marriage customs, their experience of Aboriginal missions, and the visits to Melbourne of some tribal leaders. ${ }^{15}$ Kerr was one of the first to photograph Aboriginal people. As he described it, 'when their first shyness was overcome they were never weary of sitting in any attitude, and laughed with childish glee at the results' ${ }^{16}$ Soon after his arrival at the station Kerr persuaded the local people to stage a corroboree during the day for him, giving them 'a considerable present' to do so. He was told that women could not see a corroboree in daylight, so, to add verisimilitude, he arranged for three young men, wrapped in possum skin cloaks, to pose as the audience. The resulting photographs are perhaps the earliest ever taken of a corroboree. ${ }^{17}$

Kerr's other photographs include images of Aboriginal men in possum skin cloaks with traditional weapons, and a 'young half-caste boy on opossum rug' with his toys: bull rushes, a small shield and playing sticks. ${ }^{18}$ Kerr knew some of the women and children of the camp as well. A few years after settling at Fernyhurst, he drew a portrait of

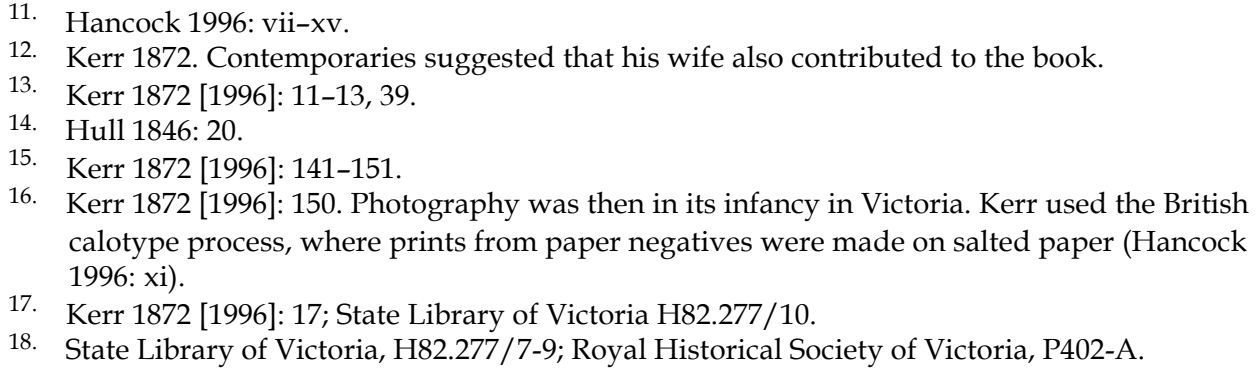


'Queen Jerrybung' or 'Jellibung', an elderly matriarch of the tribe, and a lithograph was later made of his drawing. ${ }^{19}$ A photograph taken in 1849 of his station hut and yard includes a servant who appears to be an Aboriginal woman, dressed in European clothing including a dress, bonnet and large apron. ${ }^{20}$ Kerr did not pose his neighbours in traditional dress against a 'timeless' background of the Australian bush or, generally, against the backdrop of their own homes. Instead, he posed them against the walls of a building made of dressed stringybark, which was possibly his own first home or the separate building provided as accommodation for his employees. In this way he was portraying the Indigenous people 'coming in', moving into the station complex and not remaining on the edge. His photography also hinted at the changes in Aboriginal culture wrought by the coming of Europeans. One of his most striking photographs shows a young man in a possum skin cloak who stands proudly against the backdrop of a white sheet pinned to the stringybark wall; he holds a European flintlock musket and aims it with authority away from the photographer into the distance. ${ }^{21}$ It appears from his autobiography and from the evidence of his photographs that Kerr was well-known and accepted by the Indigenous people who lived close to his station house, and that he was in a position to hear and observe much about their daily life.

\section{Kerr and the Exhibitions of 1854 and 1855}

In 1854, Kerr was about to be appointed a local magistrate and was thinking of joining the Melbourne Club. It was not yet apparent that he had been living beyond his means and that he was soon to face bankruptcy. In July that year, Kerr responded with enthusiasm when he learnt that a committee of public men in Bendigo was calling for 'specimens of the industry and resources of the colony of Victoria' to be collected and forwarded for display. They wanted material that would be displayed first in a new exhibition building in Bendigo, then in an exhibition in Melbourne, and that would then be forwarded to Paris for the 1855 Exposition Universelle.

The Bendigo Exhibition (also known as the Sandhurst Exhibition), 'the first Exhibition of Industry held in Australia', was held only three years after the enormously successful Exhibition of Industry of the Nations at the Crystal Palace in London in 1851. Victoria had not been separately represented at the London exhibition and the colonists wanted to ensure that they were properly represented at the Paris exhibition, so that they could make a significant contribution to the international stage. ${ }^{22}$ The Victorian Government appointed Exhibition Commissioners who encouraged regional committees, planned a central exhibition in Melbourne, and organised the display of a wide variety of material in a Victorian Court in Paris.

Kerr's autobiography is silent on his involvement in these exhibitions and we can only surmise why he became involved. He had exhibited before. In January 1851 he won a gold medal for 'the best colonial thoroughbred' in an exhibition organised by the Victorian Industrial Society. ${ }^{23} \mathrm{He}$ was quick to respond to the Bendigo Exhibition

19. Kerr, J 1992: 424; a copy of the lithograph is in the Dixon Library DL Pd 55. It is reproduced in Drought 1926: facing p.1.

20. State Library of Victoria, H82.277/12.

21. State Library of Victoria, H82.277/11.

22. Panton n.d. Autobiography: 115. See also Westgarth 1857: 98.

23. Argus, 3 February 1851: 2. 


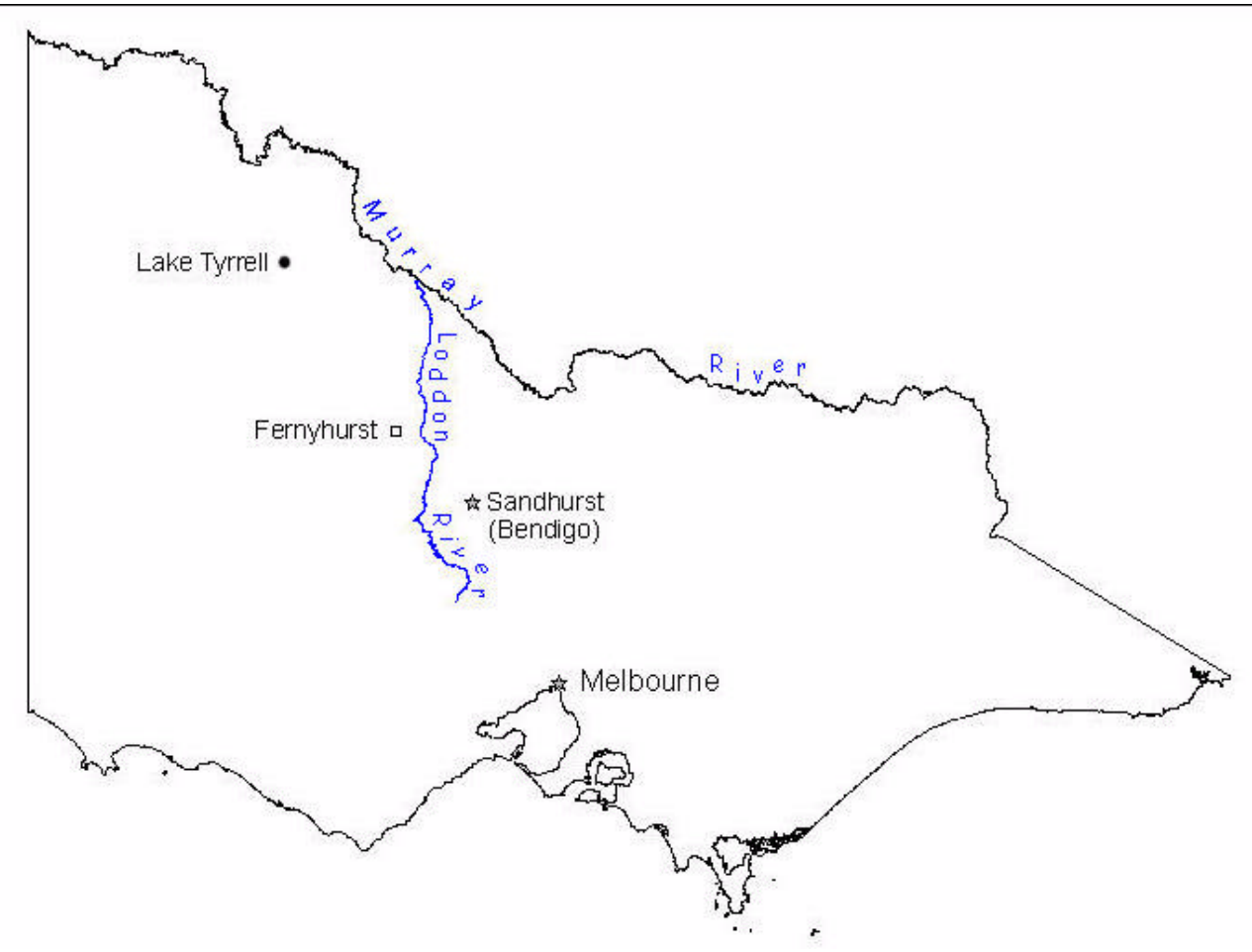

Figure 3: Map of Victoria showing locations referred to in the paper. Courtesy Peter Lilywhite, Museum Victoria

Committee's request, gathering and forwarding to Bendigo a wide range of material for display.

The collection of Indigenous material culture that John Kerr submitted under his name for the Sandhurst Exhibition was impressive in its variety and extent. As well as Aboriginal tools - shields, waddies, boomerangs, 'native tomahawks', spears and spear throwers - it included 'opossum skins worked by Aborigines', an emu skin, the 'skin of an opossum on bark', some 'native boys' play sticks', examples of women's work, particularly 'native grass wrought by lubras' and 'a kangaroo rat bag'. In addition, he displayed three items of ceremonial significance: 'emu feathers used in corrobberys [sic]', 'kangaroo rat skins, used in corrobberys', and a large curved piece of bark in the shape of an emu decorated with white ochre lines, which he later told collector RE Johns that he had seen used in corroborees. ${ }^{24}$ To round off the collection, he exhibited at least two 'native drawings on bark'. One of these showed a kangaroo and other animals being hunted, while the other - the work now at Kew - depicted Aboriginal dancers wearing emu feather headdresses. Kerr also contributed a collection of raw materials to the Bendigo Exhibition, displaying 'specimens of iron ore, gum-vines, pine-gum, lime, salt, gypsum and smelted iron ore' and 'woollen gloves and socks' made on his station from 'rough wool' ${ }^{25}$

24. Cooper 1994: 96-97. This piece is now in the British Museum, item Oc. +1281 . 


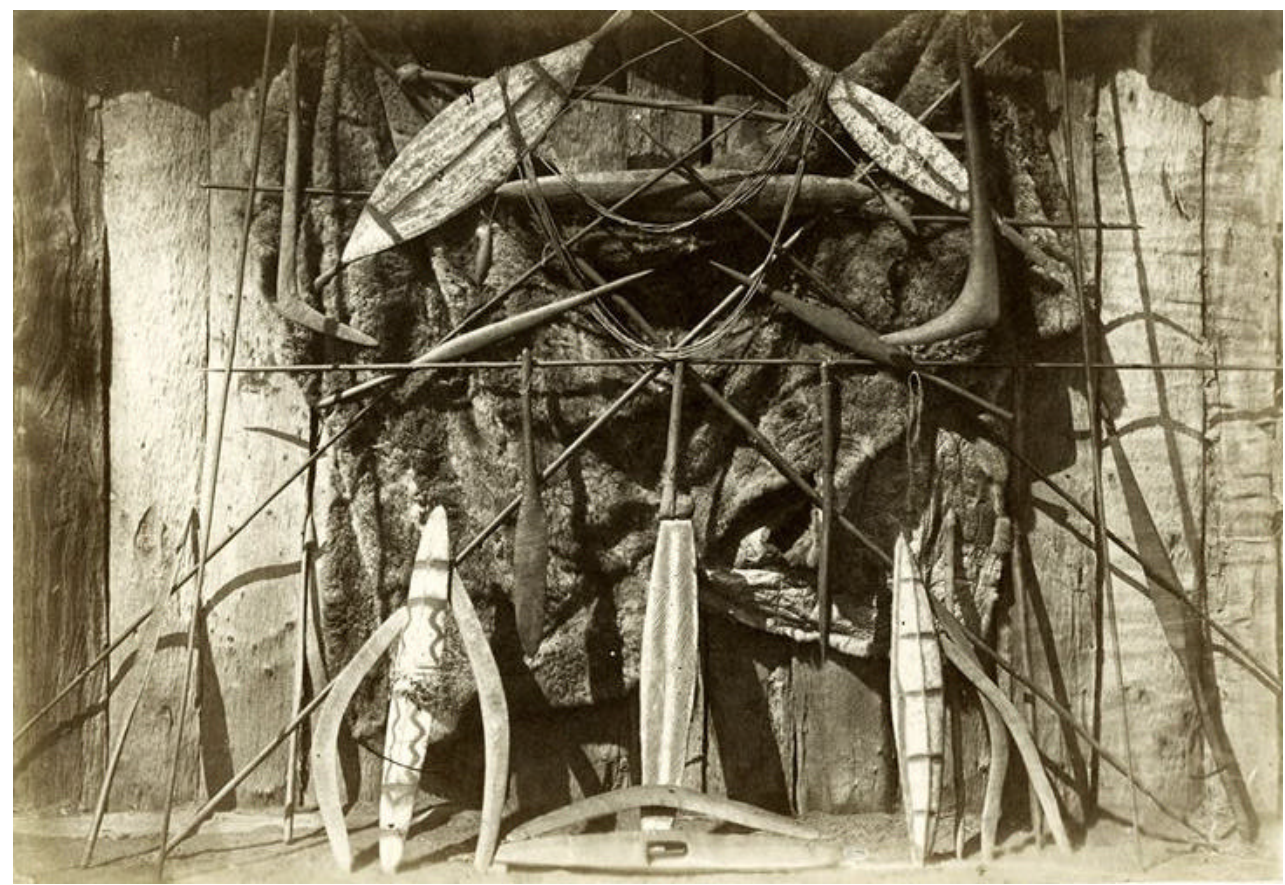

Figure 4: Display of items collected from members of 'the Loddon and Murray tribes', photographed by John Hunter Kerr c.1854. Courtesy La Trobe Picture Collection, State Library of Victoria

Kerr's collection of Aboriginal material has received little attention from historians, probably because so few pieces from it are known to have survived. Yet he was the first to present a systematic display of Aboriginal material to a wide public in Victoria. $^{26}$ His collection is also notable because it included material from women and children, as well as men. He may have photographed some of the collection at Fernyhurst before he took it to Bendigo. A lithograph of a photograph showing boomerangs, spear shields, parrying shields, two types of spears, spear-throwers, weet-weet or play sticks, clubs, a possum skin rug and fibre rope, displayed against the wall of a bark shed, was published as the frontispiece of his book in $1872 .{ }^{27}$

When the Sandhurst Exhibition opened in September 1854, the press reports described Kerr's exhibit as 'an excellent collection of weapons and various articles used by the aborigines' ${ }^{28}$ The collection included at least one example of a work-in-progress: a

25. Official Catalogue of the Melbourne Exhibition 1854: 35-36. See also Argus, 18 September 1854: 5.

26. A small collection of Indigenous artefacts, donated by squatters and William Thomas of the Aboriginal Protectorate, was on display at the Melbourne Mechanics' Institute from c.1846, but these were not collected systematically. The newly formed National Museum of Victoria did not collect Indigenous material culture, although it did display 'Aboriginal skulls' at the 1854 Melbourne Exhibition (Cannon 1991: 318; Official Catalogue of the Melbourne Exhibition 1854: 23).

27. Kerr 1872 [1996]: 153. An albumen silver print of this is in the State Library of Victoria, H30158/29. 
possum skin pinned out on bark to show how the skins were prepared before being made into cloaks. Kerr's exhibit of Indigenous industry received a silver medal at this Exhibition: the citation was for a display of 'native weapons' ${ }^{29}$ When the collection was moved to Melbourne in October 1854 and displayed in the new Exhibition Building on the corner of William and Latrobe Streets, it was placed on the mezzanine near the picture gallery, and described as 'a most interesting and elaborate collection of aboriginal implements and articles of clothing'. ${ }^{30}$ Yet the bronze medal that Kerr won in Melbourne is inscribed 'Native weapons and natural history'. ${ }^{31}$ Despite the evidence in front of them for an Indigenous material culture that was much wider and more complex than merely instruments of war and tools for the hunt, the judges appear to have interpreted the collection through eyes which noticed and recognised only the weapons.

Kerr's collections, along with samples of Victorian gold, wool and timber, and specimens of the mammals, birds, and plants of the region, were shipped to London and thence to Paris in the care of Special Commissioner Edward Bell, who was to set up the Victorian Court as part of the British Court in the new exhibition buildings along the Champs-Elysées. Bell was charged with the care of 20 packages from Victoria, including a valuable collection of Victorian gold nuggets. He had a horrible trip on the Argo: the voyage took over two months, the impressive display case that had been provided to house the Victorian gold was too large to fit in the hold and obstructed promenaders on the deck, and he seemed to quarrel with most people on board. ${ }^{32}$ When he arrived in Paris, he discovered that no formal application had been made by the Victorian authorities for space in the Exhibition. He succeeded in obtaining a very prominent position for the case of gold, but the other material, including the Aboriginal exhibits, was placed out of the mainstream in a hot, glass-roofed temporary annexe. In his report to the Chief Secretary in June 1855, Bell feared that not many people would see the Victorian exhibits. ${ }^{33}$

\section{The presentation of Indigenous material at the Paris Exhibition}

How did European Australians choose to present Indigenous material at this, the first great international exhibition to display material from mainland Australia to a European audience?

In the 1850s, the 'Exhibition of Industry' at an international exhibition implied much more than simply the display of the products of the industrial revolution. Certainly, the mechanical marvels and inventions of the machine age had evoked the greatest wonder at the London Exhibition of 1851. But the international exhibitions aimed also to show the fruits of the 'industry', 'industriousness', or 'work', of the peoples of the world. In the words of Asa Briggs: 'The values behind the exhibitions were international too. Work was hailed, mankind was treated as one, and the future of mankind was explored'. ${ }^{34}$ The products and crafts of the indigenous peoples of the

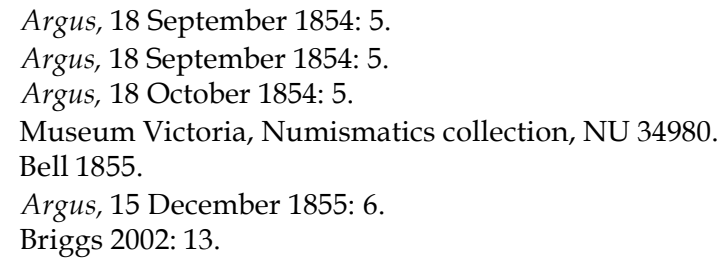


colonised world - the objects that would be dismissed as 'curios' or 'curiosities' by later generations - then formed part of the large displays presented by colonial powers and were not separated off into disconnected displays arranged by ethnicity. It was colonialism, rather than race or ethnicity, that was being displayed. ${ }^{35}$ Indigenous items were on display in the 1850 s essentially as examples of 'native industry' and adaptability, and as indicators of the workmanship and common humanity of people from all parts of the world.

As the European settlers in Victoria gathered items for the Melbourne and Paris Exhibitions, they were influenced by several strands of thought. Their overwhelming sentiment was one of pride: pride in the progress which had established towns and farms and cultural institutions in a 'wilderness' only a few short years after British settlement. There was optimism, as well, about the potential of the new land to provide raw materials that were yet to be fully exploited. They wanted to promote their new land by displaying a wide range of 'industry', and they wanted to include examples of Aboriginal industry, of the work of Aboriginal people. Although many Europeans expressed a belief that Indigenous people were being supplanted and suppressed as 'an inferior race', many of those who collected material for Paris had first-hand knowledge of the ingenuity and adaptability of their Aboriginal neighbours, and the variety and innovation of their material culture. An exhibition was a place where these strands came together. At the time of the Melbourne Exhibition in 1854, George Rusden, scholar and Exhibition Commissioner, gave a lecture at the Melbourne Mechanics Institute. He suggested that the exhibition was 'an undertaking ... for the good of work and learning' and quoted from Francis Bacon when he likened the Exhibition to a place which would be 'dedicated to the study of the works and creatures of God'. ${ }^{36}$

The theme of the industry and adaptability of Indigenous people was apparent also in the certificate designed by Ludwig Becker for the prizewinning exhibitors at the 1854 Melbourne Exhibition. Becker depicted the usual suspects - gold digger, shepherd, farmer and 'wild' Aboriginal man with boomerang and spear - but he also showed an Aboriginal bullock driver, his work for the day completed, resting in the street of a town; he was described in approval as 'attired in Guernsey, trousers and high-lows, and exhibiting the effects of his contact with the civilisation of the white man'. ${ }^{37}$

There was a further reason for displaying works of Aboriginal industry in the Melbourne and Paris Exhibitions: Victorians wanted to prove to the world that, in Victoria at least, the Indigenous people were both still working in traditional ways and adopting new ways. In London in 1851, the Tasmanian Court had included some examples of the 'works of industry' of Indigenous Tasmanians, but the Australian colonists' contribution to the Crystal Palace exhibition had been criticised by a London journalist. In a weekly paper put out during the exhibition, he listed the exhibits that showed Aboriginal industry, and marvelled at their ingenuity. He then deplored the fate of the Tasmanian Aboriginal people, and suggested that Indigenous people were probably no longer to be found in southern Australia. In October 1851 he wrote:

5enedict 1983: 41

36. Rusden 1857: 7.

37. Argus, 7 May 1855: 6; Museum Victoria, Department of Australian Society and Technology, 01.728 . 


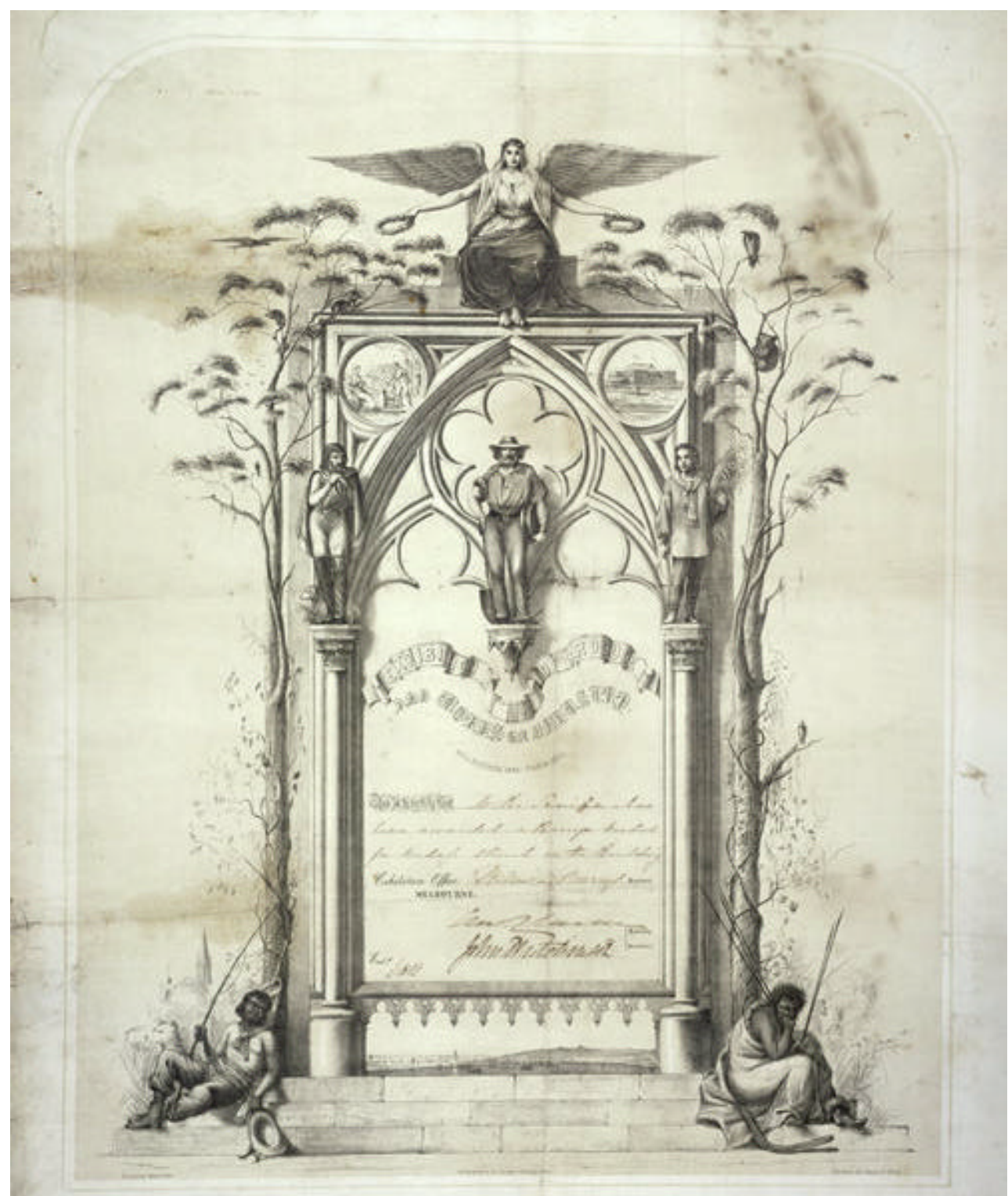

Figure 5: Ludwig Becker designed this prize certificate for the 1854 Melbourne Exhibition of Produce and Works of Industry. Indigenous people are included in the design. Collection: Museum Victoria 
There is a melancholy tribute paid in the Van Diemen's Land Department to its now extinct Aborigines. In our forty years possession of that settlement we [ie the British race] have utterly destroyed them ... Yet these poor people had tastes and industry too. ... They obtained a brilliant shell necklace by soaking and rubbing off the cuticle, and gaining various tints by hot decoctions of herbs. They procured paint by iron ore, and reducing it to powder by grind-stones. They converted sea-shells and sea-weeds into convenient water vessels; they wove baskets, and they constructed boats with safe catamarans. All these things are exhibited. Surely, then, the men whom their greedy supplanters admit to have done this ... ought not to have been hunted down ... and shut up in an island too small for even the few remaining. The New South Wales contributions offer no sign of the Aborigine's works, and probably the country contains no longer any trace of the people. ${ }^{38}$

This criticism was known in Victoria. Captain RE Pasley was one of the Commissioners of the Melbourne Exhibition and owned a copy of the publication where it had appeared. He and his fellow Commissioners may have been influenced by its content when they came to plan the 1854 Exhibition. ${ }^{39}$

The 'Special Instructions' for intending exhibitors distributed by the Exhibition Commissioners in July 1854 listed the kinds of items of natural history, metals, timber, grain and manufactured articles that would be acceptable for display for Paris. They also urged contributors to collect examples of Indigenous industry, particularly Aboriginal weapons and implements, shell necklaces, 'native food', and opossum rugs. ${ }^{40}$ If a range of 'native industry' was presented, it would prove that not all Australian colonies had destroyed their Indigenous inhabitants, and it would also show that many Aboriginal people were still undertaking traditional activities, while others were adapting to European ways. (The Victorian Exhibition Commissioners also wanted to demonstrate how British settlers had improved on Indigenous practices, so they suggested that exhibitors could collect 'opossum rugs as prepared by the Aborigines, and also as manufactured in a superior manner'. $)^{41}$

In response to these instructions Kerr submitted a complex and nuanced collection of Aboriginal objects that was designed to show the industry of Aboriginal people. Kerr's collection of material from the Loddon people, with its mix of domestic, ceremonial, women's and children's objects, as well as hunting tools and weapons, presented evidence of a variety of activities and work from a community where children played, women collected food and wove grasses into attractive containers, and men decorated their homes and participated in complicated ceremonies. It is apparent that the collection was put together deliberately, probably with the active involvement of his Indigenous neighbours, and that an attempt was made to include material made and used by a range of different people - women and children as well as men. I suggest also that the two representational bark drawings that were collected and exhibited by

38. The Crystal Palace and its contents, Issue 3, 18 October 1851: 44.

39. Pasley, Colonial Engineer, owned and exhibited in 1854 'a complete set of the medals and books connected with the Great Exhibition of 1851', Official Catalogue of the Melbourne Exhibition 1854: 33. He had the opportunity to read this criticism from London before contributing to the Special Instructions for the 1854 exhibitors.

40. Special Instructions for the guidance of local committees and intending exhibitors 1854: 24.

41. Special Instructions for the guidance of local committees and intending exhibitors 1854: 24. 
Kerr may have been deliberately commissioned or chosen as examples of Aboriginal industry and because they illustrated how some of the other items collected from the Loddon people were used.

The Loddon and Murray collection gathered by Kerr formed the bulk of the Indigenous cultural material on display in the Victorian Court in Paris. It was supplemented by a small display from the Government Museum, showing a further aspect of Aboriginal industry: 'tomahawks, in various stages of manufacture, from Phonolite' from the Mount William district. ${ }^{42}$ Some Victorian exhibitors showed objects that demonstrated contact between Aboriginal people and Europeans. Ludwig Becker exhibited a 'pencil drawing by an Aborigine' and 'two portraits of Aborigines'. ${ }^{43}$ Another Victorian exhibitor, $\mathrm{T}$ Jones, contributed a 'bullock hide halter made by Aborigines on the Murray', that showed the adaptation of old techniques to a new material and purpose. ${ }^{44}$ Kerr was not alone among the exhibitors in being interested in the 'works of the industry' of Indigenous people, in the material evidence of their innovation, productiveness and adaptability.

The theme of 'Aboriginal industry' was also evident within the NSW Court at the Paris Exhibition. It is not clear whether the NSW Commissioners followed the Victorian Commissioners in suggesting that works of Indigenous manufacture could be submitted for exhibition in Paris, but several exhibitors did submit such works. There was no equivalent to Kerr's carefully gathered and comprehensive collection, but the NSW Court included Indigenous items contributed by several different exhibitors, including 'native dillies', 'Aboriginal baskets', a boomerang and 'womera', 'several native spears and waddies', and an 'opossum rug'. There were also some examples of the adaptability of Aboriginal people in the face of contact with Europeans. Mrs Minniss exhibited 'Aboriginal knitting needles from the Tumut River' and J Hocking from Vaucluse presented 'gloves and cuffs of Aboriginal manufacture from opossum fur'. ${ }^{45}$ Many of these objects were assembled in face-to-face interactions between the exhibitors and the Indigenous people who traded or gave their items for exhibition. They were displayed as examples of Indigenous industry and included examples where traditional skills and/or materials had been adapted for a new purpose.

The exhibition of Indigenous material in Paris in the Victorian and NSW Courts contrasts with exhibitions of Aboriginal material prepared later in the century, which were generally dominated by Aboriginal weaponry. In her analysis of European representations of 'Aboriginality' in later 19th century Victoria, Lesley McCall suggested that 'the fascination of 19th century Europeans with the primitive and savage created ... an image of Aboriginality in which the portrayal of a state of primitiveness was fundamental.' $^{46}$ Particular artefacts, especially hunting and fighting implements, were thought to illustrate this principle best, and these predominated in most 19th century exhibitions, photographs of Aboriginal people, and museum displays. ${ }^{47}$ Aboriginal weapons were presented as examples of primitive technology and often exhibited so as

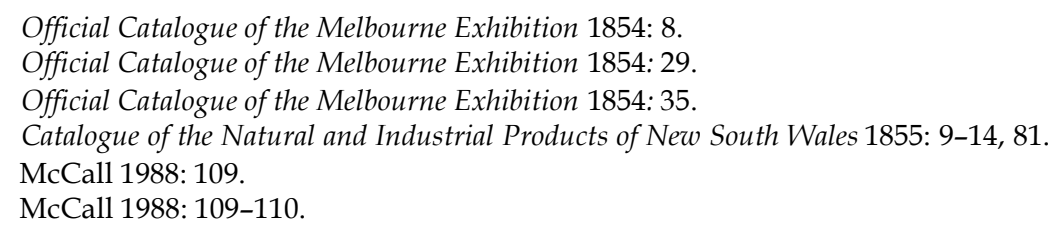


to provide a dramatic contrast with objects showing the progress and increased complexity of European technology. One example of this was RE Johns' collection of Victorian ethnographic material, displayed at the Paris International Exhibition in 1878. Tom Griffiths describes how the collection was separated out from the other Victorian exhibits, and placed at "the beginning of a series showing "the history of labour", proclaiming to the world the primitive nature of Australia's relic savages' ${ }^{48}$ Other scholars have also identified an emphasis by 19th century collectors on weapons and hunting tools. Philip Jones has suggested that museum and exhibition collections of the 19th century, with their 'bias toward weaponry', 'supported the dominant and erroneous view of Aborigines as people with little leisure, preoccupied with internecine warfare rather than with ceremonial or artistic life' ${ }^{49}$ Ilaria Vanni suggested that displays of weapons at international exhibitions placed Aboriginal people 'outside time', 'frozen', as people living in a nomadic society of hunters. ${ }^{50}$ Such displays also presented Aboriginal weapons as 'trophies', and hinted at the subjugation of the Indigenous people. ${ }^{51}$ The collections exhibited by Kerr and other colonists in 1855 were clearly more comprehensive and more nuanced than these later collections.

In Paris, Kerr's collection was entered with other collections of Indigenous and non-Indigenous material from Victoria in Section 25, 'Articles of clothing, objects of fashion and fancy', under a special section, 'Diverse collections'. It was described as 'native weapons and ornaments used in war and corroborees by the aborigines' 52 The Indigenous material was not separated out from the Victorian Court; it was included with the other works of 'industry' produced by the European settlers of the colony.

Kerr's collection was not awarded either a medal or a certificate in Paris and it appears to have been largely un-noticed. A Gold Medal went to the NSW commissioner, W MacArthur, for the NSW display of raw materials, wines, wool, wheat, and Aboriginal artefacts. The judges were impressed by the wide range of workmanship and industry in the display, suggesting that it showed both ' 1 'industrie primitive des naturels' and ' 1 'industrie déja très-développée des colons' ${ }^{53}$ Edward Bell made only one early report back to the Victorian Commissioners, ${ }^{54}$ so the Victorian exhibitors, including Kerr, waited in vain for a comprehensive account of how their material had been viewed in Paris.

At the close of the Paris Exhibition, exhibitors could choose to have their collections sold in Paris, or forwarded at their own cost to a specified destination in Britain. ${ }^{55}$ It is not clear what Kerr intended to have done with his collection, as the schedule listing the Victorian material shipped to Paris, which gave indications about the exhibitors' expectations for ultimate disposal, has unfortunately not survived. ${ }^{56}$ There was a small market for the sale of Aboriginal material within Britain. Natural history collectors like

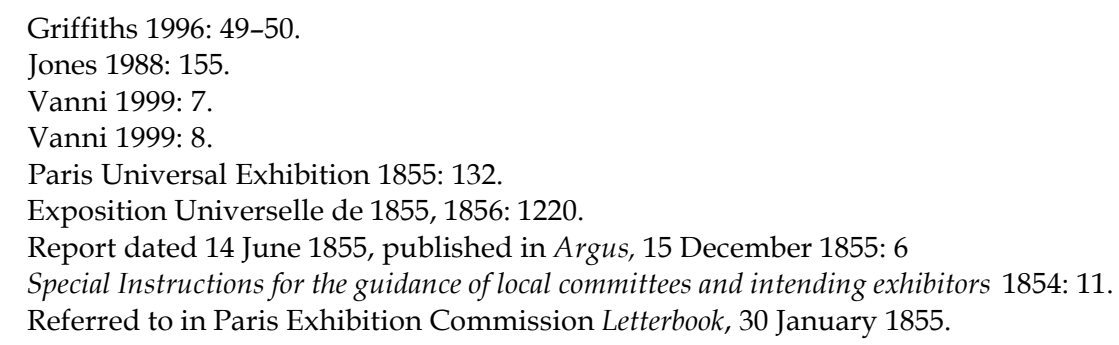


John Cotton sent Aboriginal artefacts as well as bird skins and other specimens from Victoria for sale by an agent in England, ${ }^{57}$ and Kerr may have hoped to take advantage of this trade, or he might have hoped to sell the material directly to a collecting institution in London. The British Exhibition Commissioners made it their habit to purchase significant items from international exhibitions for the great national museums. ${ }^{58} \mathrm{Sir}$ William Hooker, the Director of the Royal Botanic Gardens, visited Paris during the Exhibition in 1855 and reported to the Board of Trade on the 'remarkable objects' he saw. ${ }^{59}$ Presumably, Hooker's report formed the basis for his recommendations of possible acquisitions for the British collections, including the newly-developing Economic Botany collections at Kew. The records at Kew identify Kerr as the source of the bark drawing, so even if it was sold to the Botanic Gardens by an agent the connection with Kerr was retained.

In 1861, the Economic Botany collections at Kew contained the two bark drawings and the ceremonial piece in the shape of an emu that had been exhibited by Kerr. They were presumably kept as examples of an unusual use of a natural resource by an indigenous people. The drawing with the corroboree was on display in that year, when it was described as 'bark of a Eucalyptus, on which rude drawings have been made by the aborigines of Australia' ${ }^{60}$ Later in the century, one bark drawing and the ceremonial piece were recognised as having ethnographic value, and were transferred to the British Museum of Mankind in 1866 and 1880. As already noted, the second bark drawing slipped out of sight and has only recently been re-discovered and its significance recognised.

The three works continue to be held by the London collecting institutions and it is probably unlikely that they will be repatriated in the near future. They are among many other items of Indigenous manufacture from Australia, collected before 1860 and sold or donated to the British national collections. Few of them are as well-provenanced as these three items.

\section{Description of the work at the Royal Botanic Gardens}

I have suggested above that Kerr may have chosen to collect, or the Aboriginal people to make, the two bark drawings because they illustrated how some of the other objects on display were used. The drawing now in the British Museum shows boomerangs, spear-throwers, spears, shields and clubs in use by hunters. The drawing now in the Royal Botanic Gardens depicts how the 'emu feathers used in corrobberys' - also part of Kerr's collection - were worn. A quick stylistic examination suggests that the two bark etchings that Kerr collected were by different artists. Kerr seems to have been among those 19th century European artists who took an interest in the art of the Aboriginal people. ${ }^{61}$ He thought of himself as an artist - his drawing of 'Queen Jellibung' was made into a lithograph - so it was perhaps natural for him to seek out artists

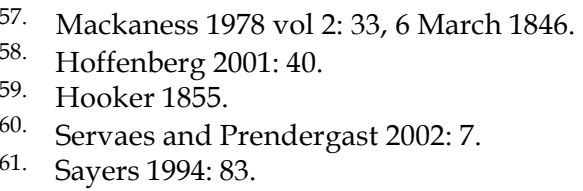


among the Aboriginal people he knew and to collect or commission their work as part of the wider collection, and as an example of another type of 'industry'.

The etching in Kew is on a curved piece of bark. It shows 13 figures, arranged roughly in four groupings. Most are recognisably human and eight of them are clearly male. Many of the figures appear to be dancing in a corroboree formation. Five of the figures wear headdresses made from emu feathers. Two men wear four shafts of emu feathers, two wear two shafts and one figure only one shaft. At least three of the males are wearing two to four other hair ornaments. Nine of the figures are carrying objects: boomerangs, waddies or tomahawks, and other items that are now unclear and have not been identified. Some of the smaller figures are partly limbless, and least resemble humans. Two figures are stretched out as if on the ground. One of these may be depicted as if climbing a tree after a possum. Three figures may represent a group of people sitting on the ground and observed from behind - or perhaps a woman and two children using digging sticks. ${ }^{62}$

The drawing is arranged in a linear style in four distinct levels: two dancers at the top, one dancer or hunter with four reclining or seated figures on the second level, three decorated dancers on the third layer, with three smaller images - two dancers and one indistinct reclining figure - at the bottom. This linear format is also followed by the other bark drawing from the Loddon now in the British Museum, where there appear to be three rows of figures; and in the bark drawing in Museum Victoria where human and animal figures are arranged roughly in five levels. Some of the sitting and reclining figures in the Kew bark drawing are very similar to those in the Museum Victoria bark drawing from Lake Tyrrell. The Kew drawing seems to be the only one of the three where the artist has begun to delineate facial features for some of the figures.

In the bark drawing in Kew the dancers appear to be naked, with their genitalia clearly depicted and exaggerated in size. There does not appear to be any suggestion of a fibre girdle. This is surprising given EM Curr's report of the Bangerang people in corroboree that 'in all cases the performers wore a belt around the loins from which depended, both before and behind, a thick bunch of opossum skin throngs which hung halfway down to the knees' ${ }^{63}$ The drawing is one of the few illustrations showing emu feather headdresses, as distinct from cockatoo feathers, in a corroboree in Victoria. Curr described how 'the hair of the head ... was confined either by a netted fillet or a narrow band of twisted opossum skin ... a plume of emu or cockatoo feathers being frequently inserted in it'. ${ }^{64}$ In 1895 Albert AC le Souef, the son of a Victorian Protector of Aborigines and later a member of the Aborigines Protection Board, wrote about a Goulburn River corroboree that he had seen in 1841. He described the dancers, 'painted with streaks of white pipeclay', who wore 'on their heads red or white bands, in which were stuck feathers of the white or black cockatoo, or bunches of the tail feathers of the $\mathrm{emu}^{\prime}{ }^{65}$ The drawing shows the dancers with their feet very wide apart. It is not a detailed representation of all aspects of the corroborees seen by Europeans: the dancers

\footnotetext{
62. Servaes and Prendergast 2002: 7-9. Additional comments by the author, who had a brief opportunity to see the work in London in 2002.

63. Curr 1883 [1965]: 135.

64. Curr 1883 [1965]: 134

65. Sculthorpe 1990: 176.
} 
are not decorated, and there is no head-band supporting the emu feather headdresses. The tufts of green leaves that Curr describes 'borne tightly around each ankle', and the 'rolls of fur around the thick part of the dancers' arms', are not shown. ${ }^{66}$ There were no examples of these objects among the collection that Kerr sent to Paris.

There are obvious parallels between the bark drawing and the work of Tommy McRae who lived on the Murray around Wahgunyah and was drawing with ink on paper for a European audience from the 1860s. McRae also grouped his figures in several levels and drew scenes of corroborees and hunting expeditions. McRae's corroboree formations are much tighter and more disciplined than in the bark drawing, but the dancers are depicted in a similar stance, heads turned to one side and hands holding instruments or tools. ${ }^{67}$ One of McRae's drawings of a 'war dance' seems to show emu feather headdresses. ${ }^{68}$ Similarly, south-eastern Aboriginal artists William Barak and 'Mickey of Ulladulla' both grouped the figures that they drew on paper in a linear arrangement. Both artists depicted dancers in corroboree with feet wide apart and legs strongly braced. ${ }^{69}$

Carol Cooper has suggested that figurative drawings were the visual language used by Indigenous people for communication with outsiders and the uninitiated. ${ }^{70}$ This type of drawing was therefore eminently suitable for a work that was to travel far from its point of origin to Melbourne and then to Europe. The Kew drawing awaits full interpretation and detailed comparison with related works, a project that is beyond the scope of this paper.

In 2004, Museum Victoria turns 150. This year also marks the sesquicentenary of the display in Melbourne of Kerr's collection from the Loddon and Murray people. The Museum has negotiated with the Royal Botanic Gardens and the British Museum to borrow the two bark etchings, so that these significant and scarcely known works can be seen again in Australia. They will be on display at the Melbourne Museum from March to June 2004.

\section{Acknowledgments}

I wish to thank Caroline Servaes of the Royal Botanic Gardens, Kew, for alerting staff at Museum Victoria to the existence of the bark drawing. I would also like to thank Lindsay Kerr at Kew for permission to reproduce his schematic drawings, student Fiona Davis for alerting me to John Cotton's collecting activities, and staff at the State Library of Victoria for their assistance in locating rare books and manuscripts. Thanks also to two anonymous referees and to my colleagues Louise Partos and Gary Presland for their comments on this paper.

66. Curr 1883 [1965]: 135.

67. Cooper and Urry 1981: 81-88. See also Sayers 1994: 27-49.

68. Tommy McRae: 'Lachlan Blacks war dancing', State Library of Victoria H14224, reproduced in Sayers 1994: 126.

69. William Barak: 'Ceremony', National Gallery of Victoria 1215B/5, reproduced in Sayers 1994: 120; 'Mickey of Ulladulla': 'Corroboree', National Gallery of Australia, 91.870, reproduced in Sayers 1994: 130.

70. Eagle 1999: 242. 


\section{References}

\section{Primary sources}

The Argus, September-December 1854, January, December 1855.

Bell, Edward 1855, Diary, 9 January - 14 March, 1855, LaTrobe Library, MS 8961.

Colonial Secretary's Correspondence, Paris Industrial Exhibition, 1854, VPRS 1189, Consignment P0000, Unit 227, Victorian Public Records Office, Melbourne.

Drought, M L 1926, Extracts from old journals written by Frederic Race Godfery, (pioneer) of Boort Station, Loddon District, Victoria, 1846-1853. Compiled in 1926 by his eldest daughter M.L.Drought, Tytherleigh Press, Melbourne.

Exposition Universelle de 1855, 1856, Rapports du Jury Mixte International publié sous la direction de S.A.I. Le Prince Napoléon, President de la Commission Impériale, Imprimerie Impériale, Paris.

Kerr, John Hunter 1872 [1996], Glimpses of life in Victoria by a resident, Miegunyah Press, Carlton.

Mackaness, George (ed) 1978, The correspondence of John Cotton, Victorian pioneer, $1842-$ 1849 in three parts, Review Publications, Dubbo, NSW.

NSW Exhibition Commissioners 1855, Catalogue of the natural and industrial products of New South Wales: exhibited in the Australian Museum by the Paris Exhibition Commissioners: Sydney, November 1854, Reading and Wellbank, Sydney.

Official catalogue of the Melbourne Exhibition 1854, in connexion with the Paris Exhibition, 1855, 1854, F Sinnett \& Company, Melbourne.

Paris Universal Exhibition 1855, Catalogue of the works exhibited in the British Section of the Exhibition: with notes of the commercial progress of the United Kingdom, under the respective classes, in French and English: together with exhibitors' prospectuses, prices current $E$ c, Chapman \& Hall, London.

Panton, Joseph nd, Papers, LaTrobe Library MS 10071.

---- nd, Autobiography, LaTrobe Library MS 7727.

Paris Exhibition Commission, June 1854 - May 1862, 'Letterbook', La Trobe Library, H 17247.

Special Instructions for the guidance of local committees and intending exhibitors, Exhibition, Melbourne 1854 - Paris 1855, 1854, Office of the Commission, Melbourne.

The Crystal Palace and its contents: being an illustrated cyclopaedia of the Great Exhibition of the Industry of All Nations 1851 embellished with upwards of five hundred engravings, 1851-52, W Clark, London.

\section{Secondary sources}

Benedict, Burton 1983, The anthropology of World's Fairs: San Francisco's Panama Pacific International Exposition of 1915, Lowie Museum of Anthropology in association with Scolar Press, London and Berkeley.

Briggs, Asa 2002, 'The history of International Exhibitions', in Environment Australia, (2002) Nomination of Royal Exhibition Building and Carlton Gardens, Melbourne, by the Government of Australia for Inscription on the World Heritage List, Canberra.

Cannon, Michael 1991, Old Melbourne Town before the gold rush, Loch Haven Books, Main Ridge, Victoria. 
Clark, Ian D (ed) 1988, The Port Phillip Journals of George Augustus Robinson: 8March 7April 1842 and 18 March - 29 April 1843, Monash Publications in Geography No. 34 Melbourne.

Cooper, Carol and J Urry 1981, 'Art, Aborigines and Chinese: a nineteenth century drawing by the Kwatkwat artist Tommy McRae', Aboriginal History 5(1): 80-88.

Cooper, Carol 1994, 'Traditional visual culture in south-east Australia', in Aboriginal artists of the nineteenth century, Andrew Sayers (ed), Oxford University Press, Melbourne: 91-109.

Curr, E M 1883 (1965), Recollections of squatting in Victoria, then called the Port Phillip District (from 1841 to 1851), Melbourne University Press, Melbourne.

Eagle, Mary 1999, 'Traditions of representing the land in Aboriginal art', Art E Australia 37: 236-244

Ellis, Robert (ed) c1851, Official descriptive and illustrated catalogue of the Great Exhibition, in three volumes, Spicer Bros, London.

Griffiths, Tom 1996, Hunters and Collectors: the antiquarian imagination in Australia, Cambridge University Press, Melbourne.

Groger-Wurm, Helen M 1973, Australian Aboriginal bark paintings and their mythological interpretation. Volume 1: Eastern Arnhem Land, Australian Institute of Aboriginal Studies, Canberra.

Hancock, Marguerite 1996, 'Introduction', in Kerr, 1872 [1996] Glimpses of life in Victoria by a resident, Miegunyah Press, Carlton: vii-xx.

Hoffenberg, Peter 2001, An Empire on display: English, Indian and Australian exhibitions from the Crystal Palace to the Great War, University of California Press, Berkeley.

Hooker, William 1855, Notes of some Remarkable Objects exhibited in the French, Foreign, and British Colonial Departments of the Paris Universal Exhibition. Furnished to the Board of Trade by Sir William Hooker [and others], Chapman \& Hall, London.

Hull, W 1846, Remarks on the probable origin and antiquity of the Aboriginal Natives of New South Wales, deduced from certain of their customs, superstitions and existing caves and drawings, in connection with those of the nations of antiquity, by a Colonial Magistrate, J. Pullar \& Co, Melbourne.

Jones, Phillip 1988, 'Perceptions of Aboriginal Art: a history' in Dreamings: the art of Aboriginal Australia, Peter Sutton (ed),Viking, Victoria: 143-179.

Kerr, Joan (ed) 1992, The Dictionary of Australian artists: painters, sketchers, photographers to 1870, Oxford University Press, Melbourne.

Krefft, G 1862-65, 'On the manners and customs of the Aborigines of the Lower Murray and Darling', Trans. Phil. Soc. NSW.

Lloyd, GT 1862, Thirty-three years in Tasmania and Victoria, being the actual experience of the author interspersed with historic jottings, narratives and counsel to emigrants, Houlston and Wright, London.

Massola, A 1958, 'A Victorian Aboriginal bark drawing in the British Museum', The Victorian Naturalist 75(Nov): 124-127.

McCall, Lesley 1988, 'The European creation of 'Aboriginality' in nineteenth and early twentieth century Victoria: a study of material culture in historical documents, historical photographs and artefact collections', BA(Hons) thesis, LaTrobe University, Melbourne. 
Rusden, George W 1857, Gathering together for the good of work \& learning: a lecture on the occasion of the opening of the Exhibition Building in Melbourne, October 1854, George Robertson, Melbourne.

Sayers, Andrew 1994, Aboriginal artists of the nineteenth century, Oxford University Press, Melbourne.

Sculthorpe, Gaye (comp) 1990, Guide to Victorian Aboriginal collections in the Museum of Victoria, Department of Human Studies, Museum of Victoria, Melbourne.

Servaes, Caroline D and Hew DV Prendergast 2002, 'Out of the museum darkness: a mid19th century bark drawing from Victoria, Australia', Economic Botany 56(1): 7-9.

Smyth, R Brough 1878, The Aborigines of Victoria: with notes relating to the habits of the natives of other parts of Australia and Tasmania compiled from various sources for the Government of Victoria, Government Printer, Melbourne.

Vanni, Ilaria 1999, 'Objects and histories: representations of Aboriginality in exhibitions of Aboriginal objects, 1855-1957', PhD thesis, College of Fine Arts, University of New South Wales, Sydney.

Westgarth, W 1857, Victoria and the Australian gold mines in 1857 with notes on the overland route from Australia via Suez, Smith, Elder and Co., London. 